Article

\title{
Supporting Sustainable Water Management: Insights from Australia's Reform Journey and Future Directions for the Murray-Darling Basin
}

\author{
Maureen Papas \\ Honorary Fellow, Law Faculty, The University of Western Australia, Perth 6009, Australia; \\ maureen.papas@uwa.edu.au; Tel.: +44-79200-63712
}

Received: 3 September 2018; Accepted: 10 November 2018; Published: 14 November 2018

\begin{abstract}
Effective regulation of freshwater remains one of the biggest challenges facing our societies. In times of record-breaking weather extremes spurred by a changing climate, decision makers are increasingly aware of the need to formulate more effective governance to ensure the reliability, accessibility, and quality of this life-giving resource. In recent years, the Australian government has played a key role in water management. The government has managed a significant amount of water entitlements in the Murray-Darling Basin (MDB), through its Commonwealth Environmental Water Holder $(\mathrm{CEWH})$ agency, in a bid to increase river flows and thus improve the river system's environmental and ecological conditions. The CEWH is unique in many respects, and the Australian government's control of its budget and actions is a critical aspect of the Basin's sustainable long-term management. Despite the importance of this instrument, this article points out that there are serious issues with the current governance arrangements, such as inherent conflicts in the Murray-Darling Basin Authority's (MDBA) role, which is a concern raised by the Productivity Commission. This article goes on to recommend the policy changes required to address Basin-wide issues and promote sustainable practices to ensure the MDB's long-term resilience.
\end{abstract}

Keywords: Murray-Darling Basin (MDB); Basin Plan; Commonwealth Environmental Water Holder (CEWH); innovation; independent institution

\section{Introduction}

Given humanity's dependency on water, equitable allocation of this life-giving resource is essential. Central to this goal is the need to optimize water usage [1] and provide frameworks for the efficient management of particular water systems. The speed of climate change is an additional challenge for water security. With global temperatures set to remain well above average in the near future [2], uncertainty about the level of demand for water is a key issue for policy-makers responsible for maintaining an adequate supply. To address the effects of extreme temperatures on the economy, a more flexible and responsive approach that promotes both adaptive and proficient governance is essential: the former to promote the ability to absorb shock, the latter to ensure effective implementation [3].

The World Economic Forum (WEF) report, Global Risks 2015 [4], predicted an impending water crisis and emphasized the need for highly adaptive systems that minimize risk and reduce vulnerability. As global risks transcend international borders and spheres of influence, stakeholders must work together to build the trust and collaboration required to adapt to future challenges. The report goes on to cite management of the Murray-Darling Basin (MDB) river in Australia as an innovative response to extreme weather events and climate change. The most significant shift in Australian water governance took place when the federal government introduced the Water Act 2007 (Cth) [5] in response to the Millennium drought (2001-2009). The Act addressed the need to restore over-allocated rivers and 
tackle a perceived lack of cooperation and sharing of responsibility between state governments on how river system waters were managed [6]. However, Australia's reputation as a world leader in water management faces serious challenges. Limits of and barriers to implementation have hampered progress and prompted some scholars to raise concerns about the "poor state" [7] of the basin, calling into question the operations and effectiveness of the MDB management system.

Following the introduction, this article will provide a brief overview of the key factors that have prompted changes in water governance in the MDB. These factors are linked to the evolution of water law and policy in the basin, and highlight the evolving role of the federal government in water management, along with changes in how water resources are perceived and valued. The third section critically evaluates the water allocation framework in relation to the Murray-Darling Basin Plan and the Commonwealth Environmental Water Holder (CEWH). Future directions and the critical next steps required for the MDB framework to effectively manage existing water resources and meet future challenges are identified in the final section.

This article demonstrates that Australia, as one of the world's driest countries and an economy that relies on the sound management of water, has much to gain from managing its water resources effectively. As sustainable river use relies on ecosystem functions being maintained by increasing river flows, the role of the CEWH is crucial. Similarly, the health of the MDB system requires effective implementation of the Basin Plan and confidence that policies will be regularly monitored, complied with, and enforced. The Production Commission's latest five-year report (2018) [8] has warned that the MDB Plan will fail to deliver unless urgent changes are made in the Plan's implementation. The Production Commission recommends splitting the Murray-Darling Basin Authority (MDBA) into two separate bodies, with a regulator appointed to assess state compliance. This is a compelling idea, since any large-scale regulatory system requires constant oversight to monitor progress and a rigor that has so far been profoundly lacking. Australia has made innovative attempts to bring its water consumption to more sustainable levels. However, the changes required will necessitate the effective cooperation of all stakeholders and the necessary will to succeed.

\section{Water Resources Management in Australia: A Brief Background}

Australia's unique situation, in terms of land and water resources (or lack thereof), has had profound implications for the way in which water is harvested, stored, and allocated [9]. With some of the most ancient land surfaces, the country has a legacy of high levels of salinity, which, if left unmanaged, has serious implications for water quality and land productivity: excess salt reduces grain yields, biodiversity, and the allocation of freshwater in general [10]. Australia's extreme rainfall variability and consistent drying trends, both within and between years and across lengthy periods, is a serious issue. The last century has witnessed a number of prolonged droughts, including the Federation drought of 1895-1902 and the World War II drought of 1937-1945. The most recent, the Millennium drought of 2001-2009, was also the most catastrophic, severely reducing water runoff and therefore water quality, resulting in a significant loss of ecosystem functions and biodiversity [11]. At a time when there is ample evidence that global climate change poses an urgent and serious threat to life on earth [12], and that Australia will experience more heat spells, extended dry periods, fiercer bushfires, and less water [13], a comprehensive, supportive, and effective water allocation framework is of critical importance [14].

With this ecological history, the Australian government has continually had to engage in extensive water reforms to address environmental degradation and economic efficiency [15]. As such, the country has often been regarded as a global leader in water policy innovation [4], although many Australians regard the management of water resources in the MDB as more of a muddle than a model [16]. Despite these concerns, the structure of the MDB has had some success and a commitment to sustainable management has been the precursor to a number of initiatives, including the National Strategy for Ecologically Sustainable Development (ESD) in 1992, the Council of Australian Governments (COAG) in 1994, and the National Water Initiative (NWI) in 2004 [6]. However, the continual decline of 
water resources during the Millennium drought, one of the most serious the basin has experienced, severely depleted the environment and the "security of water entitlements for consumptive users" [17] (p. 4). The most significant water reform occurred when the Commonwealth of Australia (the federal branch of government) enacted the Water Act 2007 (Cth) [5] and became directly involved in MDB management to ensure state collaboration and coordination [18].

The Water Act marked an important stage in the MDB system, although the constitutional ramifications of the Act proved complex, and the reform process was marred with controversy [19]. As a precondition to investing $\mathrm{A} \$ 10$ billion to reform rural water management, legislative power over water management was referred from Australian states to the Commonwealth government [6]. A Basin-wide plan for water sustainability (discussed in more depth below) was established by the new Murray-Darling Basin Authority (MDBA), a Commonwealth government agency created to manage MDB's waters in conjunction with the Basin states [20]. Unlike its predecessor, the MDB Commission, and in a move that effectively reduces the power of state governments, the MDBA reports directly to the Australian Minister for Agriculture and Water Resources.

Central to the Water Act was the imposition of a statutory limit on water extractions across the whole MDB, ending decades of unsustainable practices. As well as establishing a Basin Plan intended to develop an integrated and sustainable approach to the Basin, a Commonwealth Environmental Water Holder (CEWH) was also created "to manage the Commonwealth's environmental water to protect and restore the environmental assets of the Murray-Darling Basin" [21] in accordance with the environmental watering plan, part of the Basin Plan. Together with a Basin-wide approach to environmental water management, creation of the CEWH effectively provides the environment with "a seat at the table" for the first time [22] (p. 695). These mechanisms are critically assessed in the following section.

\section{A New Water Allocation Framework for the MDB: Recent Developments}

The MDB is the catchment of Australia's largest river system. Spanning across four states and one territory, the MDB is located in the south-east of the country and covers an area equivalent to $14 \%$ of mainland Australia [23]. The catchment accounts for 39\% of Australia's gross value of agricultural production, therefore sustainable development and effective use of water is paramount [24]. Agriculture in the basin, often referred to as Australia's agricultural heartland, has indeed contributed to economic growth, but growth achieved by exploiting the region's water resources has gone beyond their rate of replenishment [25]. To ensure the long-term sustainability of the basin, the federal government released a guide to the MDB Plan in 2010.

\subsection{The Murray-Darling Basin Plan}

As required by the Water Act, the MDB Plan was developed by the MDBA to establish sustainable diversion limits (SDLs) for the basin as a whole, on the basis of the best scientific data available. These limits represent the amount of water, or level of "take," which if exceeded, would compromise key environmental assets and key environmental functions (Water Act, s 4) [5]. Planning on this scale was complex, in terms of the size of the basin, the development of scientific knowledge to inform the Basin Plan, and the hydrological and climatic variability across the basin [26]. In October 2010, the MDBA proposed that a range of 3000-4000 gigalitres (GL) per year across the basin be made available for the environment to mitigate the effects of what were considered inadequate environmental flows. The polarized nature of the debate about the Basin Plan raised strong reaction from irrigators, who rejected the proposed cuts to irrigation, with many arguing that the MDBA had not considered the social cost of such a policy [27]. One of the key drivers of anti-Plan sentiments was that very little consultation had been carried out with local communities and stakeholders. The problem of over-allocation had been perceived as a technical issue to be resolved by an "expert knows best approach" [19]. A more collaborative approach between governmental and non-governmental 
stakeholders would have earned the community's trust and thus supported effective and efficient implementation [28].

Following the guide's release, much work was carried out to appease community concerns and address initial SDLs estimates. The final version of the Basin Plan was adopted on 22 November 2012, and incorporated a formal public consultation process. The passing of the Basin Plan into law provided a conclusion to a reform process described as "complex, messy and, at times, irrational" [28], and yet hailed as "that rarest of political achievements in Australia: a permanent solution to a longstanding problem [19] (p. 871). The environmental reallocation agreed upon was 2750 GL to be achieved by 2019, with an interim performance review process scheduled for 2015 [29]. While these limits are central to the Basin Plan in securing the long-term health of the MDB, an extra $450 \mathrm{GL} /$ year of additional water for the environment was to be recovered through infrastructure investment expenditure, bringing total water recovery up to $3200 \mathrm{GL} /$ year [30]. However, to date, emphasis has increasingly been placed on irrigation efficiency rather than buying water entitlements. In 2015, an amendment to the Water Act limited the purchase of water entitlements to a total of $1500 \mathrm{GL}$ within the MDB [27] and scheduled a full review of the Plan in 2026, with an interim evaluation in 2018.

Additional water was made available to appease South Australia, which, being downstream, had the most to gain from efficiency and sustainable environmental flows. South Australia's government threatened a High Court challenge to secure a greater return of water to the environment, a concern supported in a report by the Commonwealth Scientific and Industrial Research Organisation (CSIRO), which indicated that increases in Basin flows of 3000 GL per year would not meet the state's environmental water requirements [31]. To ensure the South Australian government did not proceed with its legal objections, an additional $\mathrm{A} \$ 1.77$ billion over 10 years from 2014 was committed for the aforementioned extra $450 \mathrm{GL} /$ year, although the volume does not have to be delivered in full until 2024 [32].

To comply with the Basin Plan, each MDB state is required to develop its own water resource plans for each catchment and groundwater system, including accounting for water taken from the river system [33]. In other words, the ability of the federal government to promote sustainability in the basin depends on the effective, transparent, and consistent application of the Basin Plan and its interactions with state and regional water plans [34]. However, there is now significant evidence that the time required for implementation had been underestimated [35]. Initially, it was expected that the Basin Plan would be implemented in the seven-year period 2012-2019. In 2018, the Productivity Commission released the Murray-Darling Basin Plan: Five Year Assessment into the effectiveness of the MDB Plan [8]. The Commission found the Plan had made significant progress, both in terms of water entitlements recovery to "bridge the gap" between over-allocation and new SDLs, and environmental water trading [36]. However, the report warned the reform was behind schedule and urgent changes were needed to the way in which the Plan was being implemented [8].

The Productivity Commission highlighted major shortcomings in the institutional and governance arrangements that threatened effective implementation, and recommended the MDBA be divided into two separate institutions: the Murray-Darling Basin Corporation and the Basin Plan Regulator [8]. Productivity Commissioner, Jane Doolan, who is responsible for environmental issues, emphasised the need for action:

[n]ow is the opportunity to make important "stitch in time" changes to ensure delivery of an effective plan. Without immediate action, there is significant risk of less water for irrigation, the cost to taxpayers blowing out and, in the future, communities wondering whether it was all worthwhile. [37]

The report was made public as the South Australia Royal Commission was investigating widespread allegations of water theft by upstream states [38]. These events highlight, once again, that the MDB Plan is a political issue, even as the river system struggles to deal with severe drought.

Grafton and Wheeler [39] argue that in a large-scale public government programme such as the MDB reform, it is crucial to regularly monitor both diversions and return flows, and keep detailed and 
accurate records of both, especially when the aim of such expenditures is to generate public benefits: since the Water Act was enacted, A $\$ 13$ billion has been spent on water recovery. Ensuring that each Basin state undertake the necessary audit of diversions and return flows, and the implications of water recovery on local communities, will be a challenge, as ecological monitoring is costly and can be a financial burden on "cash-strapped" states [35]. Furthermore, the issue of climate change remains largely overlooked. There is considerable evidence to suggest over the next few decades the MDB will become hotter and drier, and flood less frequently [38,39]. The recent Millennium drought was a precursor of what is to come. Water management will need to adapt to worsening conditions and climate change will also result in major changes to the ecological assets and services the Basin Plan is seeking to protect [40]. There has been criticism that the MDBA does not adequately account for risks associated with climate change [41]. However, Horne [42] has suggested the aim of the Basin Plan should be to correct the balance between consumptive use and the environment on the basis of the current climate, adding that adjustments to climate change could be undertaken when the Basin Plan is reviewed in 2026. The main challenge until then will be how less water should be shared between consumptive use and the environment.

Meanwhile, the Water Act established a second institution to manage water for the environment. The federal government became more directly involved in water management when the new $\mathrm{CEWH}$ was created (Water Act, s 3) [5]. Connell argues that the CEWH gives the federal government autonomous power to shape water management in the MDB [43], despite conditions having been put in place [44]. Since 2008, the Australian government has managed a significant amount of water entitlements through the Commonwealth Environmental Water Office.

\subsection{The Commonwealth Environmental Water Holder (CEWH)}

The CEWH is the institution responsible for the management of all Commonwealth environmental water entitlements (Water Act, s 104-05) [5]. The aim of the CEWH is "to manage the Commonwealth's environmental water to protect and restore the environmental assets of the Murray-Darling Basin" [44] to improve river floodplains and wetlands. These entitlements were obtained through the Water for the Future (WFF) initiative [45]. WWF was initially an A\$12.9 billion investment over 10 years from 2008, with emphasis placed on the role of water markets to voluntarily recover water for the environment [46]. The purchase of water entitlements was "value for money" [47], delivered through voluntary sales from willing irrigators to the Australian government through a tender process. This scheme was called Restoring the Balance [46]. Reallocating water to the environment was consistent with economic modelling that indicated the value of this practice for the communities living across the MDB [48]. Some commentators have questioned the result: over the last decade there has been considerable reallocation of water from consumptive use to environmental use in the MDB, which has caused significant distress within basin communities [49]. Nevertheless, what is unclear is how the impact of environmental watering is monitored and evaluated.

The CEWH has broad management options available to deliver water over the course of the watering year, including use of the water in river or wetland; carrying over water for use in the following year; and trading water (sale or purchase) [50]. The Commonwealth environmental water holdings are large public assets valued at approximately A\$3.1 billion [51]. In 2018, the House of Representatives Standing Committee on the Environment and Energy commenced an inquiry into the management and use of Commonwealth environment water [52]. Chair of the Committee, Mr Andrew Broad MP, said the inquiry is an opportunity to understand how environmental water has been managed since 2008 and how decisions are made:

... how the Commonwealth Environmental Water Holder makes decisions about when and where to use environmental water, and to examine how the water holder taps into the local knowledge and uses the latest science in order to achieve genuine long-term environmental outcomes. [52] 
Delivering environmental water requirements across a diverse landscape such as the MDB is highly complex. One area of uncertainty relates to future inflows and the likely impact of climate change [41]. There are also considerable concerns as to the possible impact on ecosystem responses to additional water, and the need for an adaptive management framework with some flexibility in the timing, duration, and volume of environmental releases [44]. The Productivity Commission has stated that the CEWH should establish the processes it intends to use to consult and coordinate event-based watering decisions, including water managers, asset managers, and environmental water holders [8]. The Commission added that these processes should be available and documented in the CEWH's 2019-2020 annual portfolio management plan [8]. While this suggests the need to revise existing procedures and actions, then manager of the CEWH's portfolio, David Papps, declared he was confident environmental water was being competently managed across the basin, and that building knowledge and trust throughout the community had always been a key focus [51].

Despite these concerns, the creation of an environmental water holder has created space for the environment to act as a market participant, the same way as any other water user [22]. Connell has argued that this may be the most significant contribution by the current Commonwealth government-led reform [53], since the environment has "a seat at the table" for the first time [22] (p. 695). Indeed, it is widely recognized that the environment requires a share of available water for the health of rivers and wetlands, and to support the river system on which other users rely (Water Act, s 3) [5]. In January 2014, the CEWH made $10 \mathrm{GL}$ of water allocation in the Gwydir Valley available for sale through a competitive tender process [54]. The CEWH's transition from an era of managing and holding to one of trade has raised concerns that protection measures to restore the river system may be diminished, an argument strongly expressed by the Australian Greens [55].

The trading of Commonwealth environmental water holdings has a key role to play in providing an adaptive response to environmental needs [54]. However, observations suggest that an assessment of the benefits of selling against the advantages of using water to provide an environmental benefit in any given year, or carrying it over to the following year, is complex in terms of the highly variable nature of the water market, and the highly variable demands of the environment across and between seasons [53]. Ultimately, effective monitoring and the accurate evaluation of environmental water are critical to any regulatory system. As far as the Productivity Commission and other observers are concerned [8], to fully deliver the objectives of the Water Act before it is too late, key aspects of the reform must be changed.

\section{Next Phase of the Reform: What Needs to Change?}

The MDB is a highly complex system, in terms of its biophysical system and highly variable climate, as well as its legal arrangements. In recent years, the Water Act has been presented as a comprehensive solution to long-standing over-allocation issues, intended to provide a catchment-wide framework for sustainable management of the MDB. Carmody has argued that the passage of innovative laws, such as the Water Act 2007 (Cth), is only the beginning of the reform journey [56]. The success of this journey requires constant vigilance, champions committed to the success of the implementation process, and a civil society capable of holding governments to account. The Basin Plan is a significant step in resetting the balance between environmental and consumptive use of water. However, a more complex implementation stage prompted by the SDLs coming into place in 2019 creates a renewed impetus to address weaknesses and opportunities, particularly given the size of investment involved: $\mathrm{A} \$ 13$ billion in total, of which about $\mathrm{A} \$ 4.9$ billion is to be spent by 2024 [8].

The Basin Plan provides a considerably larger share of water resources for the environment than a decade earlier [57], although for a number of observers, many aspects of the reform need to change. On 12 February 2018, leading experts on the MDB signed the Murray-Darling Declaration [7] calling for: a halt on all publicly-funded water recovery associated with irrigation and infrastructure subsidies; an audit of all water recovery and planned SDLs adjustments, including expenditures and actual environmental outcomes (to date and projected), especially in terms of Basin stream flows and 
including at the Murray Mouth; and the establishment of an adequately funded, expert scientific and independent body to monitor, measure, and give advice about delivery of the Water Act 2007 (Cth). This body would be responsible for a comprehensive economic and scientific analysis of costs, benefits, and outcomes of the Basin Plan and water recovery program, and evaluations of state river management and regulation. The signatories warned that unless fundamental changes were made to the way the system is administered, the Basin's aquatic environments would remain degraded and immense amounts of public money would be spent without delivering the intended long-term results [7]. The MDBA denied the claims that the Plan's investment was not delivering benefits for the environment [58], with Chief Executive Philip Glyde stating that the Plan was a visionary long-term policy, neither expected nor intended to deliver immediate results [58]. He added it was simply not possible to repair 100 years of damage to such a vast river system overnight, or within five years [58].

The above concerns were raised as the Productivity Commission was making the case for reviewing governance arrangements in the Basin by splitting the MDBA into two separate bodies, thereby countering the inherent conflict in the Authority's two main roles: supporting Basin governments to implement the plan; and ensuring compliance with the Plan [8]. The Commission suggested the MDBA should be separated into a Basin Plan Regulator to monitor and enforce compliance with key water targets, and a Murray-Darling Basin Corporation. The latter would be governed and funded by Basin state governments and would provide the support these governments need to implement the Basin Plan [8]. There could be merit in restructuring the MDBA to give the states more responsibility to manage risk but there is a need to address what would happen in the interim. A new Basin Plan Regulator could also provide better monitoring, and improve transparency and coordination across the basin, so long as the Regulator maintained a strong culture of water compliance and enforcement in the basin, regardless of politics. Meanwhile, the MDBA's new draft Basin Compliance Compact, endorsed by the MDB Ministerial Council on 8 June 2018 (and yet to be endorsed by $\mathrm{COAG}$ ), is specifically designed to strengthen enforcement of water rules and the Basin Plan [59] and needs to demonstrate its worth.

The Australian Conservation Foundation welcomed the Productivity Commission's "clear eyed assessment of the serious governance failures that weakened the implementation of the Basin Plan at the expense of a healthy river system," but was disappointed the Commission largely ignored the impact of climate change on the Plan [37]. Jane Doolan stated that the Commission's role under the Water Act was to review how the MDBA was implementing the Basin Plan; therefore, it did not consider whether the Plan was adequate to address climate change [37], or whether the decision by the MDBA to reduce water recovery targets in the Basin would put the Plan at risk. Doolan's comments appear out of step given a history of prolonged droughts in the region and the prospect of further drought and higher temperatures [60], conditions that will create more risk and call for forward-thinking strategies, not climate change indifference. As for the recent agreement, signatories to the Murray-Darling Declaration are adamant: the passage of two amendments on 8 May 2018, to reduce environmental flows in the MDB by $70 \mathrm{GL} /$ year in the Northern Basin and 605 GL/year in the Southern Basin, in the absence of an independent and comprehensive audit of water recovery to date, will increase the risks that key objects of the Water Act will not be met and is contrary to the public interest [7]. The signatories are vehemently opposed to the Labor Party and Liberal-National Coalition allowing the passage of these amendments, despite Labor water spokesman Tony Burke maintaining that the agreement he reached with the government will put the Plan back on track [61].

Concerns about auditing and compliance have been ongoing for some time. For example, issues with water meters in the state of New South Wales (NSW), prompted by allegations of water theft, led to NSW commissioning a special report. In September 2017, a report by Ken Matthews stated that "the overall standard of NSW compliance and enforcement work has been poor" and "water-related compliance and enforcement arrangements in NSW have been ineffectual and require significant and urgent improvement" [62]. Queensland also has major failings in its metering and compliance system. These findings are of considerable concern in terms of state commitments to the MDB water recovery 
program [46], the importance of strong governance and institutions, and basin communities relying on irrigation. This is particularly true for South Australia, which relies on a healthy, uninterrupted river flow. These findings have fuelled a general consensus among observers $[46,63]$ that a properly-funded independent advisory body is required to protect the public interest by advising governments and ensuring the promises of the Water Act are delivered.

Previously, the independent National Water Commission (NWC) (2004-2014) provided advice to the Council of Australian Governments (COAG) [64] and published position statements on major issues relating to water. By identifying emerging challenges and recommending actions, these statements provided a valuable source of policy discussion and debate. A properly-funded independent body would have been proactive in its response to policy: addressing implementation issues and gaps relevant to the water recovery project; highlighting inadequate compliance and enforcement of water diversions; coordinating and facilitating monitoring and public data collection; evaluating the impact of water recovery in the basin; and monitoring expenditures and subsidies or grants for irrigation infrastructures in volumes of water. An independent institution would also have questioned the massive expenditure on buybacks and irrigation infrastructure, when much more could have been achieved for far less [47]. Subsidizing infrastructure to acquire water for the environment is based on Australian government data, which is 2.5 times more expensive than buying water entitlements directly, and could be even more expensive after accounting for reductions in return flows [7].

Although not perfect, the Plan is a momentous effort and can still deliver substantial and sustained benefits for the nation's river systems, so long as all stakeholders are committed to delivering their plan "in full and on time" [65]. Meanwhile, the CEWH provides communities with the opportunity to review the case for irrigation and restoring environmental flows, without which the entire reform programme would have been a political failure. The new institution is a sophisticated management option that can, to a certain extent, effectively represent environmental interest at an arm's length from politics and deliver efficient environmental outcomes through various delivery partners [66]. The CEWH represents a new approach to environmental water management, and it is crucial to understand the key initiative behind its creation: the allocation of legal rights to water for the environment. Developing a better understanding of environmental needs is paramount, with progressive updates on flow requirements and ecological responses that vary by season [53]. Indeed, such immense public expenditure on restoring the health of a river system requires high levels of accountability, trust, and efficiency.

Few river systems have been the subject of such intense research, or generated so much legal and political discourse. If fully implemented, the current reform will be a historically significant step towards an integrated approach to water management in the MDB. As Basin states prepare to submit their plans for delivering the promised outcomes for accreditation, confidence in the Basin Plan is waning. Given the enduring implementation and institutional weaknesses, room for improvement still exists. Australia has taken pioneering steps towards bringing its water consumption to a sustainable level. As Karkkainen has suggested, water governance in Australia may be more a muddle than a model, but the cacophony of clashing interests, ideas, recommendations, and policy proposals is nothing less than democracy at work [16]. Ultimately, striving to formulate best practice in water policy is often more of an armistice than outright victory.

\section{Conclusions}

The Australian Parliament passed the Basin Plan into law in 2012. These reforms include a series of actions and targets up to 2019 and beyond. A key feature of the Plan is to lessen surface water diversion in the MDB through the implementation of SDLs, thereby reducing over-allocation by irrigators by $27,500 \mathrm{GL} /$ year on average. When fully implemented by all states, the reforms could potentially transform the way shared water is managed and provide a new coordinated approach to water diversion in the Basin. Australia is regarded as a world leader in water policy innovation but there are problems with the way the Plan is being implemented. The Productivity Commission has recommended the MDBA be split into two institutions, one to be dedicated to compliance imperatives. 
Other commentators have advocated the need for a truly independent and well-funded entity to ensure delivery of the key objects of the Water Act. However, the new MDB Compliance Compact, agreed to by all Basin governments but pending COAG endorsement, suggests a very real prospect for change in how the basin will be managed in the future. The CEWH is an adaptive management tool that, while critical to the sustainable management of the Basin's water resources over the long-term, is not without problems. While CEWH's involvement in water trading has some implications and challenges that merit close scrutiny, its responsibility for, and representation of, the environment puts CEWH in a unique position to husband the health of the MDB river system. Ultimately, commentator's recommendations and concerns highlight the complex nature of shared water management, and that the effectiveness of public-funded reform programmes must be placed under scrutiny.

Funding: The research is not based on analysis or interpretation of data and the research received no funding.

Conflicts of Interest: The author declares no conflict of interest.

\section{References}

1. Fisher, F.M.; Huber-Lee, A. Liquid Assets: An Economic Approach for Water Management and Conflict Resolution in the Middle East and Beyond; RFF Press Book: Washington, DC, USA, 2005.

2. World Meteorological Organization. Climate Breaks Multiple Records in 2016, with Global Impacts. Available online: http:/ / public.wmo.int/en/media / press-release/climate-breaks-multiple-records-2016global-impacts (accessed on 7 September 2018).

3. Cosens, B.; Chaffin, B.C. Adaptive Governance of Water Resources Shared with Indigenous Peoples: The Role of Law. Water 2016, 8, 97. [CrossRef]

4. World Economic Forum. Global Risks 2015. Available online: http://reports.weforum.org/global-risks2015/ (accessed on 7 September 2018).

5. Australian Government. 2007. Available online: https://www.legislation.gov.au/Details/C2017C00151 (accessed on 7 September 2018).

6. Papas, M. The Proposed Governance Framework for the Murray-Darling Basin. Macquarie J. Int. Comp. Environ. Law 2007, 4, 77-90.

7. The Murray-Darling Declaration Signatories. The Murray-Darling Declaration. Available online: http: / / murraydeclaration.org/ (accessed on 7 September 2018).

8. Australian Government Productivity Commission. Murray-Darling Basin Plan: Five-Year Assessment. Productivity Commission Draft Report Overview and Recommendations. 2018. Available online: https: / / www.pc.gov.au/inquiries/current/basin-plan/draft (accessed on 7 September 2018).

9. Musgrave, W. Historical Development of Water Resources in Australia. In Water Policy in Australia: The Impact of Change and Uncertainty; Crase, L., Ed.; RFF Press: Washington, DC, USA; London, UK, 2011; pp. $28-43$.

10. Australia State of the Environment 2016. Soil: Salinity and Acidification. Available online: https://soe. environment.gov.au/theme/land/topic/2016/soil-salinity-and-acidification (accessed on 1 August 2018).

11. Van Dijk, A.I.J.M.; Beck, H.E.; Crosbie, R.S.; de Jeu, R.A.M.; Liu, Y.Y.; Podger, G.M.; Timbal, B.; Viney, N.R. The Millennium Drought in Southeast Australia (2001-2009): Natural and Human Causes and Implications for Water Resources, Ecosystems, Economy, and Society. Water Resour. Res. 2013, 49, 1040-1057. [CrossRef]

12. Brown, D. New Evidence That Climate Change Poses a Much Greater Threat to Humanity than Recently Understood Because the IPCC has been Systematically Underestimating Climate Change Risks: An Ethical Analysis. Available online: https:/ / ethicsandclimate.org/2018/09/21/new-evidence-that-climate-changeposes-a-much-greater-threat-to-humanity-than-recently-understood-because-the-intergovernmentalpanel-on-climate-change-has-been-systematically-underestimating-climate/ (accessed on 7 September 2018).

13. CSIRO. Climate Change Information for Australia. Available online: Https:/ /www.csiro.au/en/Research/ OandA/Areas/Oceans-and-climate/Climate-change-information (accessed on 1 August 2018).

14. Chaffin, B.C.; Gosnell, H.; Cosens, B. A Decade of Adaptive Governance Scholarship: Synthesis and Future Directions. Ecol. Soc. 2014, 19, 56. [CrossRef]

15. Baldwin, C.; Ross, H. Bridging Troubled Waters: Applying Consensus-Building Techniques to Water Planning. Soc. Nat. Resour. 2012, 25, 217-234. [CrossRef] 
16. Karkkainen, B.C. Multi-jurisdictional Water Governance in Australia: Muddle or Model. In Reforming Water Law and Governance: From Stagnation to Innovation in Australia; Holley, C., Sinclair, D., Eds.; Springer: Singapore, 2018; pp. 57-78.

17. Fisher, D.; Gardner, A.; Godden, L.; Gray, J.; McDonald, J.; McGrath, C.; Poh-Ling, T. Joint Statement on the Water Act 2007 (Cth) Submission to the Senate Inquiry into the Provisions of the Water Act 2007. Available online: https://www.mdbrc.sa.gov.au/sites/g/files/net3846/f/rce11-_legal_opinions_submitted_to_the_ senate_and_constitutional_affairs_reference_committee_various_2011.pdf?v=1529546286 (accessed on 7 September 2018).

18. Kildea, P.; Williams, G. Journals Excerpt: The Water Act and the Murray-Darling Basin Plan. Public Law Rev. 2011, 22, 9.

19. Skinner, D.; Langford, J. Legislating for Sustainable Basin Management: The Story of Australia's Water Act. Water Policy 2013, 15, 871-894. [CrossRef]

20. Australian Government: Murray-Darling Basin Authority. About Us. Available online: https://www.mdba. gov.au/about-us (accessed on 7 September 2018).

21. Australian Government: Commonwealth Environmental Water Office. About Commonwealth Environmental Water. Available online: http://www.environment.gov.au/water/cewo/aboutcommonwealth-environmental-water (accessed on 7 September 2018).

22. Banks, S.A.; Docker, B.B. Delivering Environmental Flows in the Murray-Darling Basin (Australia)—Legal and Governance Aspects. Hydrol. Sci. J. 2014, 59, 688-699. [CrossRef]

23. Australian Government: Murray-Darling Basin Authority. Geography. Available online: https://www. mdba.gov.au/discover-basin/landscape/geography (accessed on 7 September 2018).

24. Australian Government: Department of Agriculture and Water Resources. Irrigated Farms in the Murray-Darling Basin. Available online: http:/ / www.agriculture.gov.au/abares/research-topics/surveys/ irrigation (accessed on 7 September 2018).

25. Williams, J. Water Reform in the Murray-Darling Basin: A Challenge in Complexity in Balancing Social, Economic and Environmental Perspectives. J. Proc. R. Soc. NSW 2017, 150, 68-92.

26. Crase, L.; O'Keefe, S.; Wheeler, S.; Kinoshita, K. Water Trading in Australia: Understanding the Role of Policy and Serendipity. In Routledge Handbook of Water Economics and Institutions; Burnett, K., Howitt, R., Roumasset, J.A., Wada, C.A., Eds.; Routledge: London, UK, 2015; pp. 296-313.

27. Wheeler, S.A. Insights, Lessons and Benefits from Improved Regional Water Security and Integration in Australia. Water Resour. Ecol. 2014, 8, 57-78. [CrossRef]

28. Huitema, D.; Mostert, E.; Egas, W.; Moellenkamp, S.; Pahl-Wostl, C.; Yalcin, R. Adaptive Water Governance: Assessing the Institutional Prescriptions of Adaptive (Co)-Management from a Governance Perspective and Defining a Research Agenda. Ecol. Soc. 2009, 14, 26. [CrossRef]

29. Quiggin, J. Murray-Darling Basin: This Gratuitous Decision to Reject Science is Disastrous. The Guardian. 15 December 2013. Available online: https:/ / www.theguardian.com/commentisfree/2013/dec/16/murraydarling-basin-this-gratuitous-decision-to-reject-science-is-disastrous (accessed on 7 September 2018).

30. Australian Government: Murray-Darling Basin Authority. Basin Plan Annual Report 2015-2016. Available online: https:/ / www.mdba.gov.au/publications/mdba-reports/basin-plan-annual-report-201516 (accessed on 7 September 2018).

31. CSIRO. A Science Review of the Implications for South Australia of the Guide to the Proposed Basin Plan: Synthesis. Goyder Institute for Water Research Technical Report Series No. 11/1; Adelaide, Australia, 2011. Available online: http:/ / www.goyderinstitute.org/_r122/media/system/attrib/file/113/synthesis-sciencereview-Basin-plan.pdf (accessed on 7 September 2018).

32. Hunt, G.; Baldwin, B. Coalition Delivers Election Commitment with 1500GL Water Buyback Cap. Available online: http:/ / www.environment.gov.au/minister/hunt/2015/mr20150914.html (accessed on 7 September 2018).

33. Australian Government: Murray-Darling Basin Authority. Water Resource Plans. Available online: https: / / www.mdba.gov.au/basin-plan-roll-out/water-resource-plans (accessed on 7 September 2018).

34. Connell, D.; Grafton, Q.R. Water Reform in the Murray-Darling Basin. Water Resour. Res. 2011, 47, W00G03. [CrossRef]

35. Hart, B.T. The Australian Murray-Darling Basin Plan: Challenges in Its Implementation (Part 2). Int. J. Water Resour. Dev. 2016, 32, 835-852. [CrossRef] 
36. Department of Agriculture and Water Resources. Progress towards Meeting Environmental Needs under the Basin Plan. Available online: http:/ / www.agriculture.gov.au/water/mdb/progress-recovery (accessed on 7 September 2018).

37. Davies, A. Immediate Action Required to Salvage Murray-Darling Basin Plan, Review Warns. The Guardian. 30 August 2018. Available online: https://www.theguardian.com/australia-news/2018/aug/30/ immediate-action-required-to-salvage-murray-darling-basin-plan-review-warns (accessed on 7 September 2018).

38. Grafton, R.Q.; Pittock, J.; Davis, R.; Williams, J.; Fu, G.; Warburton, M.; Udall, B.; McKenzie, R.; Yu, X.; Che, N.; et al. Global Insights into Water Resources, Climate Change and Governance. Nat. Clim. Chang. 2013, 3, 315-321. [CrossRef]

39. Colloff, M.J.; Lavorel, S.; Wise, R.M.; Dunlop, M.; Overton, I.C.; Williams, K.J. Adaptation Services of Floodplains and Wetlands under Transformational Climate Change. Ecol. Appl. 2016, 26, 1003-1017. [CrossRef] [PubMed]

40. Pittock, J.; Finlayson, C.M. Climate Change Adaptation in the Murray-Darling Basin: Reducing Resilience of Wetlands with Engineering. Australas. J. Water Resour. 2013, 17, 161-169. [CrossRef]

41. Pittock, J.; Williams, J.; Grafton, R.Q. The Murray-Darling Basin Plan fails to deal adequately with climate change. Water J. Aust. Water Assoc. 2015, 42, 28-32. Available online: http://search.informit.com.au/ documentSummary; $\mathrm{dn}=603377005698763$;res=IELAPA (accessed on 7 September 2018).

42. Horne, J. The 2012 Murray-Darling Basin Plan-Issues to Watch. Int. J. Water Resour. Dev. 2014, 30, $152-163$. [CrossRef]

43. Connell, D. The Role of the Commonwealth Environmental Water Holder. In Basin Futures: Water Reform in the Murray-Darling Basin; Connell, D., Grafton, R.Q., Eds.; ANU Press Library: Canberra, Australia, 2011; pp. 327-338. Available online: http:/ / press.anu.edu.au/publications/basin-futures (accessed on 7 September 2018).

44. Nguyen, N.; Goesch, T.; Gooday, P. Meeting Environmental Objectives in the Murray-Darling Basin. ABARES Research Report 13.4 March 2013. Available online: http:/ / data.daff.gov.au/brs/data/warehouse/9aaw_ 001/9aaw_2013/meomdbd9aawe00220130301/MeetEnvObjMDB2013_1.0.0.pdf (accessed on 7 September 2018).

45. Connell, D.; Grafton, R.Q. Planning for Water Security in the Murray-Darling Basin. Public Policy 2008, 3, $67-86$.

46. Grafton, R.Q.; Wheeler, S.A. Economics of Water Recovery in the Murray-Darling Basin, Australia. Annu. Rev. Resour. Econ. 2018, 10, 487-510. Available online: https:/ /www.annualreviews.org/doi/10.1146/annurevresource-100517-023039 (accessed on 7 September 2018). [CrossRef]

47. Grafton, R.Q. How to Increase the Cost-Effectiveness of Water Reform and Environmental Flows in the Murray-Darling Basin. Agenda 2010, 17, 17-40. [CrossRef]

48. Grafton, R.Q.; Chu, H.L.; Stewardson, M.; Kompas, T. Optimal Dynamic Water Allocation: Irrigation Extractions and Environmental Tradeoffs in the Murray-Darling Basin, Australia. Water Resour. Res. 2011, 47, W00G08. Available online: https:/ / doi.org/10.1029/2010WR009786 (accessed on 7 September 2018). [CrossRef]

49. Wheeler, S.A.; Zuo, A.; Loch, A. Water Torture: Unraveling the Psychological Distress of Irrigators in Australia. J. Rural Stud. 2018, 62, 183-194. [CrossRef]

50. Australian Government: Commonwealth Environmental Water Office. Managing the Commonwealth Environmental Water Portfolio. Available online: Https://www.environment.gov.au/system/ files/resources /1a947b47-08ac-453b-901e-4ed59c0b76cc/files/managing-cew-portfolio.pdf (accessed on 7 September 2018).

51. Australian Government: Commonwealth Environmental Water Office. Productivity Commission Inquiry—National Water Reform. Available online: https://www.pc.gov.au/_data/assets/pdf_file/0004/ 217129/sub063-water-reform.pdf (accessed on 7 September 2018).

52. Parliament of Australia: House of Representatives Standing Committee on the Environment and Energy. Inquiry into the Management and Use of Commonwealth Environmental Water. In Media Release; 1 March 2018. Available online: https://www.aph.gov.au/Parliamentary_Business/Committees/House/ Environment_and_Energy /EnvironmentalWater/Media_Releases (accessed on 7 September 2018). 
53. O'Donnell, E. Institutional Reform in Environmental Water Management: The New Victorian Environmental Water Holder. Water Law 2012, 22, 73-84.

54. Owens, K. Trading the Commonwealth's Environmental Water Holdings. Sydney Environmental Institute. Available online: http://sydney.edu.au/environment-institute/blog/trading-water/ (accessed on 7 September 2018).

55. Australian Greens. Coalition's Water Trading Plan for Murray Darling Basin Not Solution. Available online: https:/ / greensmps.org.au/articles/coalitions-water-trading-plan-murray-darling-basinnot-solution (accessed on 7 September 2018).

56. Carmody, E. The Unwinding of Water Reform in the Murray-Darling Basin: A Cautionary Tale for the Transboundary River Systems. In Reforming Water Law and Governance: From Stagnation to Innovation in Australia; Holley, C., Sinclair, D., Eds.; Springer: Singapore, 2018; pp. 35-55.

57. Horne, J.; Guest, C. The Australian Water Policy Framework: A Rejoinder to Daniel Connell a Time to Regroup and Reassess in the Murray-Darling Basin. Global Water Forum, 7 April 2014. Available online: http:/ / www.globalwaterforum.org/2014/04/07/the-australian-water-policy-frameworka-rejoinder-to-daniel-connell-a-time-to-regroup-and-reassess-in-the-murray-darling-basin/ (accessed on 7 September 2018).

58. Keane, D.; McCarthy, M. Declaration Urges Fundamental Changes to Murray-Darling Basin Administration. ABCNews. Available online: https:/ / www.abc.net.au/news/2018-02-05/scientists-urge-changes-to-murraydarling-basin-administration/9396358 (accessed on 7 September 2018).

59. Murray-Darling Basin Ministerial Council. Murray-Darling Basin Compliance Compact. 8 June 2018. Available online: https:/ / www.mdba.gov.au/sites/default/files/pubs/Basin-Compliance-Compact_0.pdf (accessed on 7 September 2018).

60. Garnaut, R. The Garnaut Review 2011: Australia in the Global Response to Climate Change; Cambridge University Press: New York, NY, USA, 2011.

61. Davies, A. Coalition and Labor Strike Deal over Murray-Darling Basin Plan. The Guardian. 7 May 2018. Available online: https: / www.theguardian.com/australia-news/2018/may /07/murray-darling-basinplan-labor-to-decide-whether-it-will-back-key-changes (accessed on 7 September 2018).

62. Matthews, K. Independent Investigation into NSW Water Management and Compliance-Interim Report. Available online: https://www.industry.nsw.gov.au/_data/assets/pdf_file/0016/120193/Matthewsinterim-report-nsw-water.pdf (accessed on 7 September 2018).

63. Papas, M. River Basin Water Management between European Union Member States: What Can Australia Learn from Another Multi-Level Governance System? Australas. J. Nat. Resour. Law Policy 2014, 17, 153-188.

64. Council of Australian Governments. About COAG. Available online: https://www.coag.gov.au/about-coag (accessed on 7 September 2018).

65. Pittock, J. It's Not Perfect but Implementing Murray-Darling Plan in Full Can Work. The Guardian. 5 April 2018. Available online: https:/ / www.theguardian.com/environment/2018/apr/06/its-not-perfect-butimplementing-murray-darling-plan-in-full-can-work (accessed on 7 September 2018).

66. Australian Government: Department of the Environment and Energy. Delivery Partners. Available online: http:/ / www.environment.gov.au/water/cewo/delivery-partners (accessed on 7 September 2018).

(C) 2018 by the author. Licensee MDPI, Basel, Switzerland. This article is an open access article distributed under the terms and conditions of the Creative Commons Attribution (CC BY) license (http:/ / creativecommons.org/licenses/by/4.0/). 